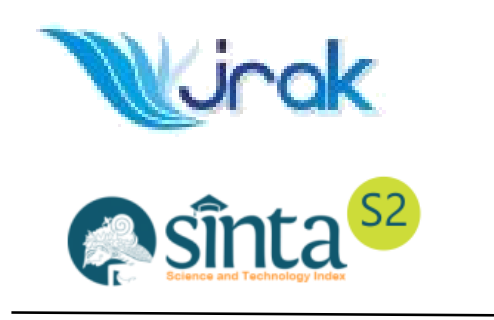

Website:

ejournal.umm.ac.id/index.php/jrak

*Correspondence:

eny@umm.ac.id

DOI: $\underline{10.22219 / \text { jrak.v11i1.16140 }}$

Citation:

Ulfa, E.K., Suprapti, E., \& Latifah, S.W. (2021). The Effect Of CEO Tenure, Capital Intensity, And Company Size On Tax Avoidance. Jurnal Reviu Akuntansi Dan

Keuangan, 11(1), 77-86.

Article Process

Submitted:

March 31, 2021

Reviewed:

April 6, 2021

Revised:

April 29, 2021

Accepted:

April 30, 2021

Published:

May 4, 2021

Office:

Department of Accounting

University of

Muhammadiyah Malang

GKB 2 Floor 3.

Jalan Raya Tlogomas 246,

Malang, East Java,

Indonesia

P-ISSN: 2615-2223

E-ISSN: 2088-0685
Article Type: Research Paper

\section{THE EFFECT OF CEO TENURE, CAPITAL INTENSITY, AND COMPANY SIZE ON TAX AVOIDANCE}

\author{
Evi Khusnita Ulfa ${ }^{1}$, Eny Suprapti ${ }^{1 *}$, Sri Wahjuni Latifah ${ }^{1}$ \\ Afiliation: \\ ${ }^{1}$ Department of Accounting, Faculty of Economics and Business, \\ University of Muhammadiyah Malang, Malang, East Java, \\ Indonesia
}

\begin{abstract}
The aim of this study is to examine the effect of CEO tenure, capital intensity, and firm size on tax avoidance which is focused on manufacture companies that listed on Indonesia Stock Exchange (IDX). Population of this study uses manufacture companies that listed on IDX period 2019, which uses purposive sampling as the method to choose samples. 88 manufacture companies are selected as the samples of this research. Data analysis technique used in this study is multiple linear regression analysis. The results of the analysis show that CEO tenure has a positive effect on tax avoidance. This means that the longer the CEO tenure will lead to an increase in tax avoidance. Capital intensity and firm size have no effect on tax avoidance. This study contributes to the reference related to factors that affect the tax avoidance.
\end{abstract}

KEYWORDS: CEO Tenure; Capital Intensity; Firm Size; Tax Avoidance. 


\section{INTRODUCTION}

Taxes are the largest source of income for the state. Taxes are used to run government programs with the aim of increasing economic growth through the development of infrastructure, public assets and other public facilities. This is evidence that tax revenue contributes greatly to state revenue. Given the very important role of taxes for the state, the government seeks to maximize revenue from the tax sector (Jusman \& Nosita, 2020). In tax revenue, the tax authorities certainly want the maximum possible tax revenue. However, when viewed from the company's point of view, tax is a burden that will reduce the company's net income. To minimize the amount of tax burden that must be paid, taxpayers usually carry outtax management. One of the tax management that companies can do is tax avoidance or tax avoidance (Suandy, 2011).

Ministry of Finance (Kemenkeu) in the fourth quarter 2019 revenue budget realization report recorded tax revenue realization of Rp. 1,546 trillion. This figure only meets the target of 86.55 percent of the estimated IDR 1,786 trillion. The phenomenon of differences in interests between the tax authorities and taxpayers, as well as the unachieved tax revenue estimates seen in the realization of the 2019 State Budget can indicateactivities tax avoidance. In addition, tax avoidance also provides great benefits, especially in the cash flow, company's. Suprapti (2017) stating that management will do tax avoidance when the cash flow is company'sunder pressure and the need to improve cash conditions, because tax avoidance can save the company's cash.

One of the tax avoidance phenomena in the international world is the case regarding the Panama papers quoted (Hadiyarroyyan \& Urumsah, 2019). The Panama Papers is a financial document containing 11.5 million confidential document data made by a law firm Mossack Fonseca from the country of Panama. The document contains a list of clients who use company services in terms of establishing new companies and managing assets abroad. The emergence of these Panama papers also proves that the high level of tax avoidance activities carried out by a number of taxpayers amidst the government's efforts to increase state tax revenue. In addition, the Panama papers have attracted public attention because they contain the names of a number of companies, conglomerates and high-ranking officials from various countries that are suspected of committing tax evasion, including some from Indonesia.

This study uses agency theory, which is looking at the differences in interests between agents and principals who seek to maximize or optimize their interests (Merslythalia \& Lasmana, 2017). In this study, there are differences in the interests of the company and the tax authorities where the company is the agent while the tax authorities are the principal. Fiskus has an interest in increasing state revenue, especially from tax revenue, while companies have an interest in increasing corporate profits. Because taxes are a burden that can reduce company profits (Doho \& Santoso, 2020).

In tax avoidance, it certainly involves company leaders as decision makers. One of the aspects that can affect tax avoidance is CEO tenure. According to Dryeng et al. (2010) in Hariyanto dan Utomo (2019) a long tenure CEO will build loyalty to the company, so that the CEO does not take tax avoidance decisions in order to take short-term benefits. While the short tenure CEO (the new CEO) will take tax avoidance to show his ability to increase the company's profit and cash flow (Goldman et al., 2017).

Rifai \& Atiningsih (2019) states that capital intensity shows how much the company invests in fixed assets. The bigger the company invests in fixed assets, the bigger the company will bear depreciation expense. This depreciation expense will later increase the company's

JRAK 11.1 
expenses and cause the company's profit to decrease, so that the company's tax burden will also decrease. If the company makes a large investment in fixed assets, it can lead to tax avoidance (Andhari, P. A. S., \& Sukartha, 2017).

Company size as a value that can classify a company into large or small categories which can be measured in various ways such as total assets or total assets of the company, stock market value, average level of sales and total sales of the company (Cahyono et al., 2016). According to Rego (2013) in Muda et al. (2020) the bigger a company, the more capable and stable it will be in generating profits which will have an effect on the higher tax burden as well. So that the larger the size of a company makes it possible to take tax avoidance actions to maintain company profits. This is because tax avoidance aims to reduce the tax burden which can reduce corporate profits.

The relationship between CEO tenure and tax avoidance has been proven empirically by Doho \& Santoso (2020) and Goldman et al. (2017) with the result that CEO tenure has an effect on tax avoidance. But on research Noviawan \& Utamie (2020) shows the results that CEO tenure has no effect on tax avoidance. In this study, it is proven that short tenure CEOs do not encourage CEOs to take tax avoidance in order to boost their reputation. So that the duration of CEO tenure does not affect tax avoidance.

Several studies on the effect of capital intensity on tax avoidance have been conducted with different results. On research Jusman \& Nosita (2020) shows that capital intensity has no effect on tax avoidance. While research from Gula \& Mulyani (2020); Dwiyanti \& Jati (2019) shows the results that capital intensity has an effect on tax avoidance.

Merslythalia \& Lasmana (2017) conducted research on the effect of executive competence, firm size, independent commissioners, and institutional ownership on tax avoidance by showing the results that firm size has no effect on tax avoidance. Different results are described in the study Rosa Dewinta \& Ery Setiawan (2016); Mahanani \& Titisari (2016) namely that company size has a positive effect on tax avoidance.

This study measures the influence of CEO tenure, capital intensity, and company size on tax avoidance in manufacturing companies listed on the Indonesia Stock Exchange (IDX) in 2019. Some previous studies have yielded different results, prompting researchers to conduct research on the influence of CEO tenure, capital intensity, and company size on tax avoidance. The importance of this research is because there are still cases of tax avoidance in companies in Indonesia that can harm the country, especially in manufacturing companies as the largest contributor to state tax revenues of $29.4 \%$. In addition, seen in the realization of tax receipts of manufacturing companies in 2019 which experienced negative growth of $1.8 \%$ which is far from the achievement of 2018 (Setiawan, 2020). This prompted researchers to prove whether CEO tenure, capital intensity, and company size influenced tax avoidance in manufacturing companies.

\section{Effect of CEO Tenure on Tax Avoidance}

Agency theory states the difference in interests between principal and agent. In this case, the tax authorities are the principal and the CEO is the agent. Short tenure CEOs (new CEOs) will take tax avoidance actions to increase the company's profit and cash flow. In

JRAK this case, the CEO's interest is to show his best ability. So the shorter the CEO tenure is, the higher the tax avoidance will be (Goldman et al., 2017). Meanwhile, the tax authorities' 11.1 interest is to obtain maximum tax revenue from taxpayers. So that the difference in the interests of the two parties creates agency conflicts. This is in line with research of Doho \& Santoso (2020) that CEO tenure has an effect on tax avoidance. 


\section{$\boldsymbol{H}_{1}$ : CEO Tenure has an effect on tax avoidance}

\section{Effect of Capital Intensity On Tax Avoidance}

Capital Intensity, namely investment activities carried out by companies that do not invest in the form of fixed assets (Jusman \& Nosita, 2020). In agency theory, the difference in interests between agent and principal is explained. In this case there is a difference in interests between company managers and tax authorities. It is in the company's manager's interest to get the desired compensation by improving company performance. Managers play an important role in tax avoidance, because managers are decision makers in tax management. So that in this case the manager can take advantage of the depreciation of fixed assets to reduce the company's tax burden. Managers will invest company funds in the form of fixed assets, with the aim of using the depreciation as a deduction from tax expense. So that company performance will increase due to a reduction in tax burden, and managers will get the desired performance compensation (Muzakki \& Darsono, 2015). Meanwhile, the tax authorities' interest is to increase tax revenue. This is in accordance with research of Gula \& Mulyani (2020) which explains that capital intensity has an effect on tax avoidance because large fixed assets will have a large depreciation expense which can also be used as tax avoidance.

\section{$\boldsymbol{H}_{2}$ : Capital Intensiy has an effect on tax avoidance}

\section{Effect of Firm Size on Tax Avoidance}

The size of the company reflects how much resources the company has, so that the size of the company is considered capable of influencing the way the company fulfills its tax obligations and can be a factor in the occurrence of tax avoidance (Muda et al., 2020). According to Nicodeme (2007) in Darmadi \& Zulaikha (2013) that companies with small size cannot be optimal in tax management because of a lack of skilled human resources, while large companies tend to have greater skilled and competent human resources to be able to do tax management. Based on agency theory, the agent, in this case the company, will maximize its performance through its resources by reducing the tax burden to maximize company profits.

Merslythalia \& Lasmana (2017) states that the larger the size of the company, the more complex the transactions are. This makes it possible that the tax authorities do not find tax avoidance in transactions in complex financial reports. So that it can encourage companies to take advantage of existing loopholes or weaknesses in statutory provisions to take tax avoidance actions from each transaction.

\section{$\boldsymbol{H}_{3}$ Firm Size has an effect on tax avoidance}

\section{METHOD}

This research is an associative study that aims to prove the effect of CEO tenure, capital intensity, and company size on tax avoidance in manufacturing companies listed on the IDX in 2019, totaling 88 companies. The sampel used in this study was selected based on following criteria : 1) Manufacturing companies listed on the IDX in 2019 2) Manufacturing companies that publish complete annual reports and financial reports for 201930 Manufacturing companies that publish financial reports in rupiah currency 4) Companies that did not experience losses in 2019. This study uses annual report data and company financial reports. Data relating to company information required for this study were obtained from www.idx.co.id. 
The dependent variable used in this study is tax avoidance, which is an active effort by the taxpayer to reduce the tax burden by not breaking the law (Mardiasmo, 2016). Tax avoidance measurement as measured by the proxy Cash Effective Tax Rate with the formula:

$$
\mathrm{ETR}=\frac{\text { cash paid for taxes }}{\text { Earning Before Tax }}
$$

The advantage of measuring CETR is that it can accommodate the shortage of book tax gaps in the calculation of commercial and fiscal taxes. So that the CETR can measure tax avoidance in the short term because it cannot be trusted by (Minnick \& Noga, 2010).

The independent variables (dependent variables) used in this study are CEO tenure, capital intensity, and company size. CEO Tenure (CEO tenure) in this study is measured by the number of years of tenure held by the CEO which is disclosed according to the annual report during the research period. The tenure of the CEO in this study uses the tenure of the company's main director. This measurement refers to research (Juliawaty \& Astuti, 2019).

Andhari, P. A. S., \& Sukartha (2017) states that capital intensity is a picture of how much company wealth is invested in the form of fixed assets. In this study, intensity capital is measured using the formula:

$$
\text { Capital Intensity }=\frac{\text { Total fixed assets }}{\text { Total assets }}
$$

Company size is the scale or value that can classify a company into large or small categories according to various ways, namely total assets or total assets of the company, stock market value, average level of sales and number of company sales. (Cahyono et al., 2016). In this study, company size is measured using the formula:

$$
\text { Size }=\operatorname{Ln}(\text { Total Assets) }
$$

Data analysis was performed using multiple linear regression methods using the SPSS (Statistical Package for Social Science) program, which is software that functions to analyze data, perform statistical calculations for both parametric and non-parametric statistics on a windows basis. (Ghozali, 2018). In this study using SPSS version 25 with the following equation:

$$
\mathrm{Y}=\mathrm{b} 0+\mathrm{b} 1 \mathrm{X} 1+\mathrm{b} 2 \mathrm{X} 2+\mathrm{b} 3 \mathrm{X} 3+\mathrm{e}
$$

Keterangan :

$$
\begin{array}{ll}
\mathrm{Y} & =\text { tax avoidance } \\
\beta 0 & =\text { konstanta } \\
\beta 1-\beta 3 & =\text { koefisien regresi } \\
\mathrm{X} 1 & =\text { CEO Tenure } \\
\mathrm{X} 2 & =\text { capital intensity } \\
\mathrm{X} 3 & =\text { ukuran perusahaan } \\
\mathrm{e} & =\text { error }
\end{array}
$$




\section{RESULTS AND DISCUSSION}

The description of research variables provides information about the characteristics of the research variables consisting of the number of objects under study, the minimum value, the maximum value, the average value (mean), and the standard deviation of each variable. The following is a descriptive statistic of each research variable:

Table 2.

\begin{tabular}{lrrrrr}
\hline & N & \multicolumn{1}{c}{ Minimum } & Maximum & Mean & \multicolumn{1}{l}{$\begin{array}{l}\text { Std. } \\
\text { Deviation }\end{array}$} \\
\hline Tax Avoidance & 88 & .001 & .711 & .30776 & .150049 \\
CEO Tenure & 88 & .000 & 48.000 & 9.96591 & 12.365552 \\
Capital Intensity & 88 & .010 & .749 & .37558 & .174159 \\
Ukuran Perusahaan & 88 & 25.049 & 33.495 & 28.46807 & 1.674183 \\
Valid N (Listwise) & 88 & & & & \\
\hline
\end{tabular}

Based on the table above, it can be seen that the number of objects studied $(\mathrm{N})$ is 88 manufacturing companies and shows the minimum value, maximum value, average value (mean), and standard deviation of each variable.

The tax avoidance variable measured using CETR shows the results of descriptive statistical analysis with the lowest (minimum) value of 0.001 and the highest (maximum) value of 0.711 . The standard value of tax avoidance variable deviation is 0.150049 with an average value (mean) of 0.30776 or $30.8 \%$. This shows that the average manufacturing company in Indonesia pays cash for taxes of $30.8 \%$, which means that companies tend to obey in paying their tax burdens. Most manufacturing companies pay their taxes for corporate income tax.

In the CEO Tenure variable, which is measured using the tenure of the company's president director, it shows that in manufacturing companies, the shortest (minimum) $\mathrm{CEO}$ tenure (minimum) is 0 years (not yet reaching 1 year of tenure). Meanwhile, the longest (maximum) is 48 years. The standard deviation value of the viariable CEO Tenure is 12.365552 with an average of 9.96591. This shows that the average tenure of CEO (main director) in manufacturing companies is 9 years.

In the capital intensity variable, the results of statistical analysis show the lowest value (minimum) of 0.010 and the highest value (maximum) of 0.749 with a standard foreign exchange of 0.174159 . The average value of the intensity capital variable is 0.37558 or $37.6 \%$. This shows that the average manufacturing company has fixed assets of $37.6 \%$ of the total assets owned. The company size variable measuring using $\mathrm{Ln}$ of total assets shows the lowest (minimum) value of 25.049 (Rp. 75,609,342,033) and the highest value (maximum) of 33,495 (Rp. 351,958,000,000,000). The average value of the company size is 28.46807 with a standard deviation of 1.674183 .

After analyzing the research description, then the cyclic assumption test is carried out which consists of the normality test, multicollinearity test, and heteroscedasticity test. Based on the results of the regression residual normality test using the Kolmogorov - Smirnov method, it shows a significance result of 0.200 . Because the results of the Kolmogorov Smirnov significance value are more than 5\% (0.05), it can be concluded that the distribution of residual values in the regression equation model is stated to be normally distributed. Then the regression model to be made the research hypothesis has fulfilled the assumption of normality.

The multicollinearity test results show that the tax avoidance variable for CEO tenure, capital intensity, and company size shows a tolerance value above 0.1 , namely 0.987 for 
CEO tenure, 0.994 for capital intensity and 0.991 for company size. The VIF calculation results also show that the VIF value on the variable CEO tenure, capital intensity, and company size is below 10, namely 1.013 for CEO tenure, 1.006 for capital intensity, and 1.009 for company size. So it can be concluded that the regression model is free from multicollinearity problems, namely there is no relationship between the independent variables.

Based on the results of the heteroscedasticity test, it shows that the significance of the CEO tenure variable is 0.178 , the capital intensity variable is 0.074 , and the company size is 0.548. These results indicate that all independent variables produce a significance value above 0.05 . So that there is no heterokesdasticity problem. The result of the coefficient of determination in this study is 0.071 , which means that as much as $7.1 \%$ of variations in the tax avoidance variable can be explained by the three independent variables, namely CEO tenure, capital intensity, and company size. While the rest $(100 \%-7.1 \%=92.9 \%)$ is explained by other causes outside the predetermined variables.

Based on the regression analysis in the study, it shows that CEO tenure has a significant effect on tax avoidance. The agency theory explains that there are differences in interests between the CEO and the tax authorities which lead to agency conflicts. CEOs with short tenure will take tax avoidance actions to increase the company's profit and cash flow. In this case, it is in the CEO's interest to show his best. So the shorter the CEO's tenure, the higher the tax avoidance will be (Goldman et al., 2017). Meanwhile, the tax authorities' interest is to obtain maximum tax revenue from taxpayers. The first hypothesis predicts a relationship between CEO tenure and tax avoidance. The result of the regression coefficient shows a negative result, which means that $\mathrm{CEO}$ tenure has a negative effect on CETR. The longer the CEO tenure, the lower the CETR, which means an increase in the level of tax avoidance. The long tenure CEO will encourage the CEO to take tax avoidance. According to O'Shannassy and Leenders (2016) in Doho \& Santoso (2020) that the company's performance will be very good when the company is led by a CEO with a long tenure. This is related to agency theory, where long tenure CEOs tend to do tax avoidance to improve company performance so that their position can be maintained for the next period. The results of the research are in accordance with the research Doho \& Santoso (2020) and Goldman et al. (2017) which shows that CEO tenure has an effect on tax avoidance.

Based on the regression analysis in the study, it shows that capital intensity has no effect on tax avoidance. In agency theory, it explains that there are differences in interests between company managers and tax officers which lead to agency conflicts. It is in the company's manager's interest to get the desired compensation by improving company performance. Managers will invest company funds in the form of fixed assets, with the aim of using the depreciation as a deduction from tax expense. So that company performance will increase due to a reduction in tax burden, and managers will get the desired performance compensation (Muzakki \& Darsono, 2015). Meanwhile, the tax authorities' interest is to increase tax revenue so that state income will increase. The second hypothesis predicts a relationship between capital intensity and tax avoidance. When a company invests in large fixed assets, it will have a large depreciation expense, resulting in a decrease in company profits. Thus, the tax to be paid by the company also decreases. However, in this study, it is proven that there is no effect of the amount of fixed assets invested by companies on tax avoidance. The results of this study support the research Jusman \& Nosita (2020) which shows that capital intensity has no effect on tax avoidance, because the company uses its fixed assets for company operations, rather than being prioritized to take advantage of its 
depreciation expense as an act of tax avoidance. It can be seen from the average fixed assets owned by manufacturing companies of $37.6 \%$, which indicates that fixed assets do not dominate the total assets of the company. This proves that manufacturing companies do not maximize investment in fixed assets to take advantage of their depreciation expense as tax avoidance.

Based on the regression analysis in the study, it shows that company size has no effect on tax avoidance. In agency theory, large companies tend to have greater skilled and competent human resources to be able to do tax management. So that large companies will have a greater chance of tax avoidance. The third hypothesis predicts that company size has an effect on tax avoidance. Large companies have high profits which result in high tax payments as well. So that it can trigger tax avoidance. However, in this study it was proven that company size has no effect on tax avoidance. The results of this study are in line with the research of Hadi (2018) which indicates that company size has no effect on tax avoidance. This is because as a taxpayer, paying taxes is an obligation for all companies regardless of the size of the company. Both large and small companies will suffer the same consequences if they violate tax provisions. Thus, large or small, the size of the company will comply in paying its taxes and will not affect tax avoidance actions. Judging from the research sample, the manufacturing company has total assets (excluding land and buildings) of more than Rp.10,000,000,000 in 2019, so it shows that all the companies studied are large companies with an average cash outlay to pay their taxes of $30,8 \%$ which means the company tends to comply in paying taxes. In addition, companies take advantage of the large amount of resources they have by using tax consulting services for tax planning, not for tax avoidance.

\section{CONCLUSION}

Based on the data that has been collected and tested using multiple regression models, it can be ignored that the variable of CEO tenure partially has a positive effect on tax avoidance. Meanwhile, the variables of capital intensity and company size have not been able to prove the effect on tax avoidance. This study contributes to the reference related to factors that affect tax avoidance. This study is expected to provide important input so that the government will tighten its supervision of companies with long CEO tenure, so that cases of tax avoidance that can harm the government can be avoided. This is because it is in accordance with the results of study which shows that CEO has a positive effect on tax avoidance. The next researcher is expected to be able to research by adding other variables that are not contained in this study so that the ability of the independent variable to explain its effect on the dependent variable can be fulfilled. Further researchers can also measure tax avoidance using other measurements, in order to provide a comparison of research results for decision making.

\section{REFERENCES}

Amri, B. (2017). Pengaruh Kompensasi Manajemen Terhadap Penghindaran Pajak Dengan Moderasi Diversifikasi Gender Direksi dan Preferensi Risiko Eksekutif Perusahaan di Indonesia. Jurnal ASET (Akuntansi Riset), 9(1), 1-14.

Andhari, P. A. S., \& Sukartha, I. M. (2017). E-Jurnal Akuntansi Universitas Udayana Pengaruh Pengungkapan Corporate Social Responsibility, Profitabilitas, Inventory Intensity, Capital Intensity dan Leverage pada Agresivitas Pajak Putu Ayu Seri Andhari ${ }^{1}$ I Made Sukartha ${ }^{2}{ }^{1}$ Fakultas Ekonomi dan Bisni. Udayana, E-jurnal Akuntansi Universitas, 18(2017), 2115-2142. 
Cahyono, D. D., Andini, R., \& Raharjo, K. (2016). Pengaruh Komite Audit, Kepemilikan Institusional, Dewan Komisaris, Ukuran Perusahaan (Size), Leverage (DER), dan profitabilitas (ROA) Terhadap tindakan Penghindaran Pajak (Tax Avoidance) Pada perusahaan Perbankan yang Listing BEI Periode Tahun 2011 - 2013. Journal Of Accounting, 2(2).

Darmadi, I. N. H., \& Zulaikha. (2013). Analisis Faktor Yang Mempengaruhi Manajemen Pajak Dengan Indikator Tarif Pajak Efektif. Diponegoro Journal of Accounting, 2(4), 1-12.

Doho, S. Z., \& Santoso, E. B. (2020). Pengaruh Karakteristik CEO, Komisaris Independen, dan Kualitas Audit Terhadap Penghindaran Pajak. Media Akuntansi dan Perpajakan Indonesia, 1(2), 70-82.

Dwiyanti, I. A. I., \& Jati, I. K. (2019). Pengaruh Profitabilitas, Capital Intensity, dan Inventory Intensity pada Penghindaran Pajak. E-Jurnal Akuntansi Universitas Udayana, 27(3).

Ghozali, I. (2018). Aplikasi Analisi Multivariate Dengan Program IBM SPSS 25. Badan Penerbit Universitas Diponegoro.

Goldman, N. C., Powers, K., \& Williams, B. M. (2017). How Does CEO Tenure Affect Income Tax Planning and Financial Reporting Decisions.

Gula, V. E., \& Mulyani, S. D. (2020). Pengaruh Capital Intensity Dan Deffered Tax Expense Terhadap Tax Avoidance Dengan Menggunakan Strategi Bisnis Sebagai Variabel Moderasi. Prosiding Seminar Nasional, 2(2012), 1-7.

Hadi, A. R. (2018). Pengaruh Faktor Keuangan Dan Non Kenangan Terhadap Nilai Perusahaan. 2, 11-22. https://doi.org/10.20885/ncaf.vol2.art8

Hadiyarroyyan, M. D., \& Urumsah, D. (2019). Sebuah literature review terhadap penelitian penghindaran pajak di jurnal terindeks Sinta. Proceeding of National ..., 1, 71-79. https://doi.org/10.20885/ncaf.vol1.art7

Hariyanto, F., \& Utomo, D. C. (2019). The Effect of Corporate Governance and Executive Compensation on Tax Aggressiveness (Empirical Study of Financial Sector Service Companies Registered on the Indonesia Stock Exchange 2014-2016). Diponegoro Journal of Accounting, 8(3), 1-14.

Juliawaty, R., \& Astuti, C. D. (2019). Tata Kelola, Kompensasi Ceo, Karakteristik Ceo, Accounting Irregularities Dan Tax Aggressiveness. Jurnal Akuntansi Trisakti, 6(2), 285. https://doi.org/10.25105/jat.v6i2.5451

Jusman, J., \& Nosita, F. (2020). Pengaruh Corporate Governance, Capital Intensity dan Profitabilitas Terhadap Tax Avoidance pada Sektor Pertambangan. Jurnal Ilmiah Universitas Batanghari Jambi, 20(2), 697. https://doi.org/10.33087/jiubj.v20i2.997

Mahanani, A., \& Titisari, K. (2016). Pengaruh Ukuran Perusahaan dan Sales Growth Terhadap Tax Avoidance. Seminar Nasional dan Call Paper Fakultas Ekonomi UNIBA Surakarta, 2(1), 212-223.

Mardiasmo. (2016). Perpajakan Edisi Terbaru 2016. CV Andi Offset.

Merslythalia, R., \& Lasmana, M. S. (2017). Pengaruh Kompetensi Eksekutif, Ukuran Perusahaan, Komisaris Independen, dan Kepemilikan Institusional Terhadap Tax Avoidance. Jurnal Ilmiah Akuntansi dan Bisnis, 117. https://doi.org/10.24843/jiab.2016.v11.i02.p07 
Minnick, K., \& Noga, T. (2010). Do corporate governance characteristics influence tax management? Journal of Corporate Finance, 16(5), 703-718. https://doi.org/10.1016/j.jcorpfin.2010.08.005

Muda, I., Abubakar, E., Akuntansi, M., Ekonomi, F., \& Sumatera, U. (2020). Pengaruh Ukuran Perusahaan, Profitabilitas, Leverage, dan Manajemen Laba terhadap Penghindaran Pajak Dimoderasi oleh Political Connection. Jurnal Riset Akuntansi dan Keuangan, 8(2), 375-392. https://doi.org/10.17509/jrak.v8i2.22807

Muzakki, M. R., \& Darsono. (2015). Pengaruh Corporate Social Responsibility Dan Capital Intensity Terhadap Penghindaran Pajak. E-Jurnal Akuntansi, 4(3), 445-452.

Noviawan, L. A., \& Utamie, D. N. (2020). Managerial tenure. 3(1), 1-14.

Rifai, A., \& Atiningsih, S. (2019). Pengaruh Leverage, Profitabilitas, Capital Intensity, Manajemen Laba Terhadap Penghindaran Pajak. ECONBANK: Journal of Economics and Banking, 1(2), 135-142. https://doi.org/10.35829/econbank.v1i2.48

Rosa Dewinta, I., \& Ery Setiawan, P. (2016). Pengaruh Ukuran Perusahaan, Umur Perusahaan, Profitabilitas, Leverage, Dan Pertumbuhan Penjualan Terhadap Tax Avoidance. E-Jurnal Akuntansi Universitas Udayana, 14(3), 1584-1615.

Setiawan, D. A. (2020). Ini Realisasi Pajak 2019 per Sektor Usaba, Manufaktur Terkontraksi. DDTC News. https://news.ddtc.co.id/ini-realisasi-pajak-2019-per-sektor-usahamanufaktur-terkontraksi-18317?page_y $=331$

Suandy, E. (2011). Perencanaan Pajak (ke-5). Salemba Empat.

Suprapti, E. (2017). Pengaruh Tekanan Keuangan Terhadap Penghindaran Pajak. Jurnal Reviu Akuntansi dan Kenangan, 7(2), 1013. https://doi.org/10.22219/jrak.v7i2.15

Tandean, V. A. (2016). Good Corporate Governance Dan Ukuran Perusahaan Pengaruhnya Pada Tax Avoidance. Jurnal Ilmiah Akuntansi dan Bisnis, 11(1), 54-62. https://doi.org/10.24843/jiab.2016.v11.i01.p07 